\title{
PEMAHAMAN OTONOMI DAERAH DALAM PERSFEKTIF UNDANG-UNDANG DASAR 1945 PASAL 18 TERHADAP KEUTUHANNKRI \\ (Study Tentang Tingkat Keberhasilan Pelaksanaan Otonomi Daerah Kabupaten/Kota di Wilayah III Cirebon)
}

\author{
Oleh \\ Sugianto \\ IAIN Syekh Nurjati - Cirebon \\ Email : sugianto@yahoo.com
}

\begin{abstract}
Regional autonomy becomes a sacred thing post 1998 reformation. Many debates about regional autonomy as manifestation decentralization of government power encourage the government seriously in realizing the concept of regional autonomy in honesty, willingness and consequence, because discourse and concept of regional autonomy has a long history in line with the history of Indonesia Republic. The regulation number 22 year 1999 and regulation number 25 year 1999 which are enhanced by the regulation number 32 year 2004 and regulation number 33 year 2004 about regional government are answers for all questions about reconstruction relationship between central and regional government. All law products become formulation that gives new color in improving the relationship between central and regional government. In substantial from those regulation it is stated how far government political will in carry on regional autonomy policy in real, wide and responsible. The purposes of this research are; firstly to know the level of success of the implementation of regional autonomy in the third region of Cirebon city, according to the second constitution amendment article 18 Jo regulation number 32 year 2004 about regional government. Secondly, the purpose of this research is to know the implementation of regional autonomy in the third region of Cirebon city in the framework of Unitary State of Indonesia Republic. According to the regulation number 32 year 2004 as the implementation article 18 of 1945 constitution the second amendment. Thirdly are to know and to understand the implementation of
\end{abstract}


regional autonomy in the third region of Cirebon City, according regulation number 32 year 2004 in the perspective of article 18 of 1945 constitution the second amendment can influence the integrity of NKRI.

Keyword : Autonomy, Regional, NKRI.

\section{Abstrak}

Otonomi daerah menjadi sesuatu yang disakralkan pasca reformasi 1998. Banyaknya perdebatan seputar otonomi daerah sebagai manifestasidari desentralisasi kekuasaan pemerintahan mendorong pemerintah untuk secara sungguh-sungguh merealisasikan konsep otonomi daerah secara jujur, penuh kerelaan dan konsekwen mengingat wacana dan konsep otonomi daerah memiliki sejarah yang sangat panjang seiring berdirinya republik Indonesia ini.Munculnya UU Nomor 22 Tahun 1999 dan UU Nomor 25 Tahun 1999 yang disempurnakan dengan UU Nomor 32 Tahun 2004 dan UU Nomor 33 Tahun 2004 mengenai Pemerintahan Daerah merupakan jawaban atas berbagai pertanyaan seputar rekonstruksi hubungan Pemerintah pusat dan daerah. Produk-produk hukum tersebut menjadi suatu formulasi yang akan memberi warna baru dalam upaya memperbaiki hubungan Pemerintah pusat dan daerah. Secara substansial dari Undang-undang tersebut menyatakan besarnya keinginan politik (political will) Pemerintah untuk menyelenggarakan kebijakan otonomi daerah yang benar-benar nyata, luas dan bertangung jawab.Tujuan penelitian ini adalah pertama, Untuk mengetahui tingkat keberhasilan pelaksanaan otonomi daerah kabupaten/kota di Wilayah III Cirebon menurut Pasal 18 UUD 1945 Amandemen ke-II jo UU Nomor 32 Tahun 2004 tentang Pemerintahan Daerah.kedua, Untuk mengetahui pelaksanaan otonomi daerah kabupaten/kota di Wilayah III Cirebon dalam kerangka Negara Kesatuan Republik Indonesia Menurut UU Nomor 32 Tahun 2004 sebagai implementasi Pasal 18 UUD 1945 amandemen ke II.ketiga, Untuk mengetahui dan memahami pelaksanaan otonomi daerah kabupaten/kota di Wilayah III Cirebonmenurut UU Nomor 32 Tahun 2004 dalam presfektif Pasal 18 UUD 1945 amandemen ke II dapat berdampak terhadap keutuhan NKRI.

Kata Kunci : Otonomi, Daerah, NKRI. 


\section{A. Pendahuluan}

Gelombang perubahan yang melanda Indonesia pasca jatuhnya pemerintahan orde baru, membuka wacana dan gerakan baru diseluruh aspek kehidupan masyarakat, tak terkecuali dalam dunia pemerintahan. Semangat yang menyala-nyala untuk melakukan reformasi, bahkan cennderung melahirkan euphoria, memberikan energi yang luar biasa bagi bangkintya kembali wacana otonomi daerah, setelah hampir sepertiga abad ditenggelamkan oleh rezim otoritarian orde baru dengan politik stick and carrot-nya. Salah satu unsur reformasi total itu adalah tuntutan pemberian otonomi yang luas kepada daerah kabupaten dan kota.

Dalam sejarah perkembangannya kebijakan otonomi daerah di Indonesia mengikuti pola seperti pada bandul jam yaitu beredar antara sangat sentralistik dan desentarlistik. Apabila kebijakan yang dilaksanakan sangat sentralistik maka bandulnya akan ditarik kembali kepada arah titik keseimbanganm desentralistik demikian pula sebaliknya. Hal ini dapat dilihat dengan mengikuti perkembangan pelaksanaan otonomi daerah melalui peraturan perundang-undangan yang mengaturnya sejak dari UU nomor 1 tahun 1945 sampai dengan sekarang UU Nomor 32 tahun 2004.

Dalam pasal 18 UUD 1945 amandeemen ke II, dikatakan bahwa, "Pembagian daerah Indonesia atas dasar daerah besar dan daerah kecil, dengan bentuk susunan pemerintahannya ditetapkan dengan Undang-Undang.Pelaksanaan otonomi daerah tersebut dilakukan 
dengan cara memberikan kewenangan penuh pada daerah kabupaten/kota hal ini ditegaskan dalam Pasal 18 UUD 1945 amandemen kedua, yaitu;

1. Negara kesatuan Republik Indonesia dibagi atas daerah propinsi, daerah Kabupaten/Kota, mempunyai pemerintahan daerah yang diatur dengan undang-undang.

2. Pemerintahan daerah propinsi, daerah kabupaten, dan kota dapat mengatur serta mengurus sendiri urusan pemerintahan menurut azas otonomi dan tugas pembantuan.

3. Pemerintahan daerah provinsi, daerah kabupaten, dan kota memiliki Dewan Perwakilan Rakyat Daerah yang anggotaanggotanya dipilih melalui pemilihan umum.

4. Gubernur, Bupati dan Walikota masing-masing sebagai kepala pemerintahan daerah Provinsi, Kabupaten dan Kota dipilih secara demokratis.

5. Pemerintah daerah menjalankan otonomi seluas-luasnya, kecuali urusan pemerintahan yang oleh UU ditentukan sebagai urusan pemerintahan pusat.

6. Pemerintahan daerah berhak menetapkan peraturan daerah dan peraturan-peraturanlain untuk melaksanakan otonomi dan tugas pembantuan.

7. Susunan dan tata cara penyelenggaraan pemerintah daerah diatur dalam Undang-undang.

Dalam Pasal 18 ayat (1) sampai (7) UUD 1945 tersebut pelaksanaannya ditetapkan dengan UU Nomor 32 Tahun 2004 tentang Pemerintahan Daerah yang dalam proses pembentukannya mengalami 7 kali perubahan yaitu sebagai berikut: UU Nomor 1 Tahun 1945, UU Nomor 22 Tahun 1948, UU Nomor 1 Tahun 1957, UU Nomor 18 Tahun 1965, UU Nomor 5 Tahun 1974, UU Nomor 22 Tahun 1999 dan terakhir UU Nomor 32 Tahun 2004 tentang Pemerintahan Daerah. UU Nomor 32 Tahun 2004 tentang Pemerintahan Daerah sebagai 
implementasi terhadap Pasal 18 UUD 1945 Amandemen ke II menjelaskan bahwa daerah kabupaten/kota harus mempunyai kebebasan dan kemandirian dalam melaksanakan otonomi yang seluasluasnya dengan tujuan untuk mensejahtrakan rakyatnya. Adapun prinsip-prinsip yang penting dalam UU Nomor 32 Tahun 2004 tentang Pemerintahan Daerah antara lain: (1) Prinsip otonomi yang seluasluasnya, (2)Prinsip otonomi yang nyata, (3)Prinsip otonomi yang bertanggungjawab.

Dalam rangka penyelenggaraan pemerintahan daerah yang diamanatkan UUD 1945, Pemerintahan Daerah kabupaten/kota yang mempunyai kewenangan untuk mengatur dan mengurus sendiri urusan pemerintahan menurut asas otonomi dan tugas pembantuan.Pemberian otonomi luas kepada daerah di arahkan untuk mempercepat terwujudnya kesejahtraan masyarakat melalui peningkatan pelayanan, pemberdayaan dan peran serta masyarakat.Disamping itu melalui otonomi luas, daerah di harapkan mampu meningkatkan daya saing dengan memperhatikan prinsip demokrasi, pemerataan, keadilan, serta potensi dan keanekaragaman daerah dalam sistem NKRI.

Pemberian otonomi luas kepada daerah di arahkan untuk mempercepat terwujudnya kesejahtraan masyarakat melalui peningkatan pelayanan, pemberdayaan dan peran serta masyarakat.Peningkatan pelayanan, pemberdayaan dan peran serta masyarakat menjadi kata kunci pelaksanaan otonomi daerah, karena semangat dari otonomi adalah mendekatkan pelayanan pemerintah 
kepada masyarakat yang selama pemerintahan orde baru lebih bercorak senralistik.

Berdasarkan hal itu, perlu dikaji sejauh mana pelaksanaan otonomi daerah kabupaten/kota di Wilayah III Cirebon yang diamanatkan dalam Undang-Undang, dimana Bupati/Walikota sebagai kepala daerah dalam penyelenggaraan pemerintahan bersama DPRD harus mengatur dan mengurus sendiri urusan pemerintahannya menurut asas otonomi dan tugas pembantuan dengan cara berkompetisi menggali potensi pengelolaan Pendapatan Asli Daerah (PAD)dengan tujuan untuk mewujudnya kesejahteraan masyarakatnya, tentunya harus melakukan politik action sesuai kewenangan daerah kabupaten/kota, hal tersebut belum bisa di lakukan pemerintah daerah karena adanya pengaruh pemeritah pusat masih kuat, selama ini daerah kabupaten / kota mengedepankan politik will semata.

\section{B. Permasalahan}

Berdasarkan uraian latar belakang masalah di atas, maka yang menjadi rumusan masalah yang menjadi fokus kajian dalam penulisan ini adalah:

1. Bagaimana tingkat keberhasilan pelaksanaan otonomi daerah kabupaten/kota di Wilayah III Cirebon menurut Pasal 18 UUD 1945 Amandemen ke-II jo UU Nomor 32 Tahun 2004 tentang Pemerintahan Daerah?

2. Sejauhmana pelaksanaan otonomi daerah kabupaten/kota di Wilayah III Cirebon dalam kerangka Negara Kesatuan Republik 
Indonesia Menurut UU Nomor 32 Tahun 2004 dalam jiwa Pasal 18 UUD 1945 amandemen ke-II?

3. Apakah pelaksanaan otonomi daerah kabupaten/kota di Wilayah III Cirebonmenurut UU Nomor 32 Tahun 2004 dalam presfektif Pasal 18 UUD 1945 amandemen ke II dapat berdampak terhadap keutuhan NKRI?

\section{Metode Penelitian}

Metode penelitian yang digunakan dalam penelitian ini yaitumenggunakan metode yuridis normatif yaitu dengan pendekatan ilmu hukum yang mengenal tiga lapisan ilmu hukum (rechtleer) yaitu dogmatik hukum, teori hukum dan filsafat hukum dan kepustakaan (library research) dengan teknik bahan hukum primer, bahan hukum sekunder, bahan hukum tertier. Hasil penelitian ini menunjukkan daerah Kabupaten/Kota di Wilayah III Cirebon (Kabupaten/Kota Cirebon, Kabupaten Kuningan, Kabupaten Indramayu dan Kabupaten Majalengka) mampu melaksanakan otonomi daerah berdasarkan tingkat keberhasilan dengan baik sesuai yang diamanatkan di dalam Undangundang Nomor 32 Tahun 2004 sebagai pengganti Undang-undang Nomor 22 tahun 1999 tentang Pemerintahan Daerah yang kemudian dijelaskan dalam Pasal 18 UUD 1945 amandemen ke II bahwa Pemerintah Daerah kabupaten/kota berwenang untuk mengatur dan mengurus sendiri urusan pemerintahan menurut asas otonomi dan tugas pembantuan. Hal ini dapat memberikan dampak positif dalam sebuah akumulasi Indeks Pembangunan Manusia (IPM) di Wilayah III Cirebon 
khususnya dalam bidang pelayanan dasar yang meliputi penyelenggaraan pendidikan, pelayananan kesehatan, serta daya beli masyarakat.

\section{Pembahasan}

1. Tingkat Keberhasilan Daerah Kabupaten/Kota di Wilayah III Cirebon dalam Pelaksanaan Otonomi Daerah

Pelaksanaan desentralsasi dan otonomi daerah di Indonesia dalam konstitusi NKRI menurut UUD 1945 terdapat dua nilai dasar yang dapat dikembangkan yakni nilai unitaris dan nilai desentralisasi teritorial. Nilai dasar unitaris dapat diwujudkan dalam pandangan bahwa Indonesia tidak akan mempunyai kesatuan pemeritah lain di dalamnya yang bersifat negara artinya kedaulatan yang melekat pada rakyat, bangsa dan negara $R I$.

Dengan demikian bahwa desentralisasi merupakan instrument dicapainya tujuan bernegara dalam kerangka kesatuan bangsa (national unity) yang demokratis (Democratic Goverment). Dalam konteks Pasal 18 UUD 1945 selalu harus diperhatikan keseimbangan antara kebutuhan untuk menyelenggarakan desentralsasi dengan kebutuhan memperkuat kesatuan nasional. Oleh sebab itu ciri-ciri umum penyelenggaraan desentralisasi dan otonomi daerah di Indonesia menurut UUD 1945 adalah;

1. Kesatuan pemerintah daerah merupakan hasil pembentukan oleh pemerintah, bahkan dapat dihapus oleh Pemerintah melalui proses hukum.

2. Dalam rangka desentralisasi, di Wilayah Indonesia dibentuk daerah Propinsi dan daerah Propinsi dibentuk daerah kabupaten dan kota sebagai daerah otonom. 
3. Sebagai konsekwensi dalam butir I dan II, maka kebijakan desentralisasi dilakukan oleh pemerintah sedangkan penyelenggaraan otonomi daerah dilaksanakan oleh pemerintah daerah.

4. Hubungan antara pemerintah pusat dan pemerintah daerah adalah bersifat tergantung (dependent) dan hirarkhi (subordinate). Hal ini berbeda dengan hubungan antara hubungan antara negara bagian dengan pemerintah federal yang menganut prinsip federalisme yang sifatnya Independen dan koordinatif.

5. Penyelenggaraan desentralisasi menuntut persebaran urusan pemerintahan oleh pemerintah kepada daerah otonom sebagai badan hukum publik.

Otonomi adalah kebebasan dan kemandirian (Vrijheid dan zelftandigheid) satuan pemerintahan lebih rendah untuk mengurus dan mengatur sebagian urusan pemerintahan. Urusan pemerintahan yang boleh diatur dan diurus secara bebas dan mandiri itu menjadi atau merupakan urusan rumah tangga satuan pemerintahan yang lebih rendah tersebut, bahwa kebebasan dan kemandirian merupakan hakekat isi dari otonomi. ${ }^{1}$

Akan tetapi untuk melaksanakan otonomi daerah dalam bingkai kesatuan NKRI tentunya tidak lepas dari tiga asas yaitu asas desentralisasi, asas dekonsentrasi, dan asas tugas pembantuan (medebewind). Desentralisasi adalah penyerahan wewenang pemerintahan oleh pemerintah pada daerah otonom untuk mengatur dan mengurus urusan pemerintahan dalam sistem NKRI. Dekonsentrasi adalah pelimpahan wewenang pemerintahan oleh pemerintah kepada

Bagir Manan, Perjalanna Historis Pasal 18 UUD 1945 (Perumusan dan Undangundang Pelaksanaannya), UNSIKA Karawang tahun 1992. h/m.1 
gubernur sebagai wakil pemerintah dan atau perangkat pusat didaerah. Tugas pembantuan, sedangkan tugas pembantuan adalah penugasan dari pemerintah kepada daerah dan atau desa dari pemerintah provinsi kepada daerah Kabupaten/Kota.

Istilah otonomi daerah dan desentralisasi sebenarnya mempunyai pengertian yang berbeda, istilah daerah lebih cenderung berada pada aspek politik kekuasaan negara (political aspect), sedangkan desentralisasi lebih cenderung berada dalam administarasi aspek (administrative aspect). Sebaiknya bila dilihat dari sharring of power (kerja sama dalam pelaksanaan kekuasaan antara pemerintah pusat dengan daerah) kedua istilah tersebut mempunyai keterkaitan yang erat dan tidak dapat dipisahkan.

\section{Pelaksanaan otonomi daerah kabupaten/kota di Wilayah III} Cirebon.

\section{a. Subtansi Pelaksanaan Otonomi Daerah Kabupaten/Kota}

Peraturan Perundang-undangan tertentu sebagai peraturan pelaksana terhadap UU Nomor 32 Tahun 2004 tentang Pemerintahan Daerah dan UU Nomor 33 Tahun 2004 tentang Perimbangan Keuangan Pemerintah Pusat dan Daerah. Bahwa peraturan pelaksana tersebut wajib dibuat sebagai implementasi dari UU tentunya merupakan hal yang wajib disiapkan oleh badan yang berwenang membuatnya, jika peraturan pelaksana tersebut tidak di buat, hal tersebut tidak dapat di berlakukan secara efektif. 
Pentingnya Pelaksanaan Peraturan Perundang-undangan telah disadari oleh pembuat undang-undang, dalam hal ini yang di tegaskan dalam UU Nomor 10 Tahun 2004 tentang pembentukan peraturanperundang-undangan, pasal 7 ayat (1) Hierarki Peraturan Perundang-undangan meliputi sebagai berikut UUD 1945, UndangUndang atau Peraturan pemerintah pengganti undang-undang ( Perpu ), Peraturan Pemerintah, Peraturan presiden, Peraturan daerah.

Beberapa peraturan pelaksana yang merupakan perintah dari UU Nomor 32 Tahun 2004 dapat di klasifikasikan menjadi dua kelompok yaitu dibuat oleh pemerintah pusat seperti Undangundang, Peraturan Pemerintah, Peraturan Presiden dan yang dibuat oleh daerah Kabupaten/Kota bersifat Perda, Peraturan kepala daerah, peraturan bersama kepala daerah sebagai tindak lanjut peraturan pelaksanaan terhadap UU tersebut.

\section{b. Kesiapan Daerah Kabupaten/Kota dalam Melaksanakan}

\section{Otonom Daerah.}

Adanya kewenangan yang diberikan begitu luas oleh pemerintah pusat kepada daerah Kabupaten/Kota di Wilayah III Cirebon (Kabupaten/Kota Cirebon, Kabupaten Indramayu, Kabupaten Kuningan, dan Kabupaten Majalengka) dalam rangka otonomi daerah yang di amanatkan UU Nomor 32 Tahun 2004 tentang Pemerintahan Daerah. Namun di sisi lain bahwa dengan otonomi daerah, kemandirian daerah Kabupaten/Kota tersebut belum maksimal dalam melaksanakan kewenangannya masih rentan 
adanya interpensi dari Pemerintah pusat, salah satunya terbukti daerah Kabupaten/Kota tersebut belum mampu menggali potensi yang ada di daerahnya sesuai kewenangan yang telah di desentralisasikan.

Pelaksanaan Pemerintah daerah Kabupaten/Kota di Wilayah III Cirebon (Kota/kab Cirebon, Kabupaten Kuningan, Kabupaten Indramayu, Kabupaten Majalengka) sejak otonomi daerah di gulirkan berdasarkan UU Nomor 22 Tahun 1999 yang di ganti dengan UU Nomor 32 Tahun 2004 tentang Pemerintahan daerah. Bahwa dalam PP Nomor 41 Tahun 2007 tentang Pedoman Organisasi Perangkat Daerah di tegaskan kelembagaan Organisasi Perangkat Daerah (OPD) pemerintah daerah Kabupaten/Kota di wilayah III Cirebon setiap daerah berbeda, sesuai dengan kebutuhan dan kemampuan daerah masing-masing tentunya harus ada koordinasi serta komunikasi kelembagaan antara pemerintah pusat dan daerah.

Namun setiap daerah Kabupaten/Kota di wilayah III Cirebon dengan jumlah penduduk kurang lebih 6.344 .068 jiwa mengedepankan peningkatan Indek Pembangunan Manusia (IPM) secara bertahap dan ditetapkan pemerintah. Urusan pemerintah daerah Kabupaten/Kota di Wilayah III Cirebon yang wajib di laksanakan sesuai urusan wajib yaitu berkaitan dengan pelayanan dasar seperti Pendidikan Dasar, Kesehatan, Pemenuhan Kebutuhan Hidup Minimal, Prasarana Lingkungan Dasar, sedangkan urusan yang bersifat pilihan terkait erat dengan potensi unggulan dan kekhasan daerah. 
Pelaksanaan otonomi daerah merupakan salah satu upaya pendekatan penyelenggaraan pelayanan publik dengan kewenangan yang dimiliki bahwa pemerintah daerah dituntut mampu untuk meningkatkan daya jangkau masyarakat terhdap berbagai pelayanan publik khususnya yang berkaitan dengan kebutuhan dasar. Salah satunya menggunakan tingkat kepuasan masyarakat terhadap berbagai pelayanan publik diantaranya yaitu bidang kesehatan, bahwa penurunan angka kematian bayi menjadi salah satu indikator peningkatan pelayanan dasar dibidang kesehatan.

Pencapaian pelayanan dibidang pendidikan merupakan salah satu indikator kinerja daerah dalam pemenuhan kebutuhan dasar masyarakat yang diamanatkan didalam Pasal 31 UUD 1945 "bahwa setiap warga negara berhak terhadap pendidikan" baik di daerah Kabupaten/Kota bahwa peningkatan bidang pendidikan dari tahun ke tahun mengalami peningkatan yang signifikan. Pencapaian pelayanan dibidang daya beli masyarakat merupakan salah satu indikator kinerja daerah dalam penyelenggaraan pemerintahan daerah yang dituntut untuk mengangkat masyarakat dari keterpurukan walaupun dalam pencapaiannya ketika dibandingkan dengan pelayanan lainnya tidak mengalami kenaikan secara signifikan atau fluktuatif.

Dalam menggali potensi Pendapatan Asli Daerah Sementara (PADS) setiap daerah Kabupaten/Kota di Wilayah III Cirebon berbeda, di samping itu sesuai PP Nomor 38 Tahun 2007 tentang Pembagian Urusan Pemerintah Propinsi, daerah Kabupaten/Kota di samping mendapat realisasi penerimaan Pajak Bumi Bangunan (PBB), 
Surat Kendaraan Bermotor (SKB), Bea Perolehan Hak atas Tanah \& Bangunan (BPHTB), dan APBN. Hal ini akan menjadi target Anggaran Pendapatan Belanja Daerah (APBD). Namun setiap daerah Kabupaten/Kota di Wilayah III Cirebon mempunyai potensi unggulan yang berbeda diluar kontek organisasi perangkat daerah (OPD) dan Lembaga teknis daerah, misalnya Kabupaten Kuningan selain sektor obyek pariwisata dan sumber mata air, Kabupaten Indramayu adanya sumber migas (Minyak Gas) Pertamina Balongan, Kota Cirebon sebagai kota perdagangan dan jasa, Pelabuhan dan BAT, Kabupaten Cirebon adanya Transportasi jalan tol.

Berdasarkan hasil analisis Penulis bahwa peningkatan Pendapatan Asli Daerah Sementara (PADS) dan Anggaran Pendapatan Belanja Daerah (APBD) tiap Daerah Kabupaten/Kota di Wilayah III Cirebon ada peningkatan secara signifikan dari setiap Tahun anggaran. Hal ini didasarkan atas adanya pelayanan dasar yang merupakan urusan pemerintahan yang bersifat wajib bagi daerah Kabupaten/Kota meliputi: Peningkatan Pendidikan dasar, Penyelenggaraan Kesehatan, Pemenuhan kebutuhan hidup minimal, serta daya beli, dan Prasarana lingkungan dasar. Sedangkan urusan pemerintahan yang bersifat pilihan terkait dengan potensi unggulan dan kekhasan daerah Kabupaten/Kota. Sehingga menurut UU Nomor 32 Tahun 2004 tentang Pemerintahan Daerah dapat memberikan harapan baru bagi daerah Kabupaten/Kota, dimana dengan pelaksanaan otonomi ini diharapkan potensi-potensi daerah Kabupaten/Kota dapat tergali dengan tujuan untuk 
mensejahterakan masyarakatnya agar lebih meningkat. Akan tetapi ketika dilihat dari tingkat keberhasilan yang belum maksimal terhadap potensi daerah masing-masing dengan tujuan untuk mensejahterakan masyarakat hal ini tidak mengakibatkan kegagalan dalam pelaksanaan otonomi daerah.

Mengenai kualitas aparatur pemerintah daerah yang handal dan berbobot, J. Kristiadi sebagaimana yang dikutip oleh S.H. Sarundajang, memberikan tolok ukur penilaian dengan cara memberikan ciri-ciri di dalam melakukan tugas sebagai aparatur pemerintah daerah, yaitu: ${ }^{2}$

a. Tanggung gugat yaitu berkenaan dengan meningkatnya kesadaran tentang keinginan dari aparatur negara untuk memberikan pertanggung jawaban (accountability) dan kewenangan memegang tanggung gugat. Dalam hal ini aparatur negara harus bertindak, tetapi dalam cara bertindak harus dapat mempertanggung jawabkan kewenangannya.

b. Transparan (keterbukaan) bertalian dengan keinginan menyelenggarakan administrasi negara yang terbuka dan mudah dijabarkan yangt berlandaskan konstitusional dan keabsahannya, dan apalagi era sekarang yang bertepatan dengan pelaksanaan otonomi daerah adanya Implementasi UU Nomor 14 Tahun 2008 Tentang Imformasi Publik, Bahwa pelaksanaan penyelenggaraan administrasi emerintahan harus transparan dan aquntabilitas.

c. Efisien dan Efektip, yaitu berhubungan dengan kemampuan yang tinggi untuk mengoptimalkan kemanpaatan segala sumber daya yang ada baik sumber daya manusia (SDM), Sumber daya Keuangan, serta

2 Sarundajang, Arus Balik Kekuasaan Pusat Ke Daerah, Jakarta: PustakaSinar, 2007, hlm. 7. 
Potensi sarana dan prasarana yang tersedia dalam rangka pelaksanaan tugas pelayanan yang maksimal.

d. Partisipatif, jaminan perorangan, kelompok atau kesatuan masyarakat di dalam masyarakat keseluruhan telah terlibat, baik secara langsung maupun tidak langsung dalam menyatakan keinginan-keinginan dan harapanharapan mereka terhadap pemerintah.

e. Bersih, dalam arti prilaku seluruh aparatur negara dapat di pertanggung jawabkan baik di lihat dari segi peraturanperundang-undangan, moral serta sikap tindak tanduknya dalam melaksanakan tugas negara.

Walaupun daerah Kabupaten/Kota dengan pelaksanaan otonomi daerah yang diamanatkan dalam UU Nomor 32 Tahun 2004 tentang Pemerintahan daerah, bahwa Pemerintah daerah harus mempunyai sumber daya manusia (SDM) dan sumber daya keuangan yang memadai, namun jika tidak di tunjang dengan sarana dan prasarana yang cukup memadai, maka aktipitas pemerintah akan berjalan tersendat-sendat dengan sendirinya.

3. Dampak Pelaksanaan Otonomi Daerah kabupaen/kota Menurut UUNomor 32Tahun 2004 Terhadap Keutuhan NKRI

Kata "dampak" dalam tulisan ini di masukan sebagai "akibat hukum" artinya akibat hukum dari pelaksanaan terhadap UU Nomor 32 Tahun 2004 tentang pemerintahan daerah terhadap keutuhan NKRI.

Pelaksanaan Desentralisasi dan otonomi daerah yang diamanatkan dalam UU Nomor 32 Tahun 2004 tentang Pemerintahan Daerah dapat dilacak dalam kerangka Konstitusi 
NKRI, dalam UUD 1945 terdapat dua nilai dasar yang dikembangkan yakni nilai unitaris dan nilai desentralisasi. Nilai dasar unitaris diwujudkan dalam pandangan bahwa Indonessia tidak akan mempunyai kesatuan pemerintah lain didalamnya yang bersifat negara. Artinya kedaulatan yang melekat pada rakyat, bangsa dan negara RI tidak akan terbagi pada kesatuan-kesatuan pada pemerintahan regional atau lokal.

Terkait dengan pelaksanaan otonomi daerah yang menjadi kewenangan daerah kabupaten/kota yang bersifat pilihan yang meliputi urusan pemerintahan yang secara nyata ada dan berpotensi untuk meningkatkan kesejahtraan masyarakat, sesuai dengan kondisi, kekhasan dan potensi unggulan di daerah bersangkutan, disamping itu ada beberapa hal yang menjadi kewenangan pemerintah pusat yaitu politik luar negeri, pertahanan, keamanan, yustisi, moneter da fiscal nasional serta agama (Pasal 10 ayat (3) UU Nomor 32 Tahun 2004) dan PP Nomor 38 Tahun 2007 tentang pembagian urusan pemerintahan antara pemerintah, pemerintah daerah propinsi, dan pemerintah daerah Kabupaten/Kota, Pasal 2 ayat (2).

Sebagai konsekwensi dari prinsip tersebut, maka diperlukan pengaturan yang sistematis yang menggambanrkan adanya hubungan berjenjang baik yang berhubungan dengan koordinasi, pembinaan dan pengawasan. Dalam PP Nomor 38 Tahun 2007 Pasal 4 ayat (1) bahwa pembagian urusan pemerintahan berdasarkan kriteria eksternalitas, akuntabilitas, dan efisiensidengan memperhatikan 
keserasian hubungan antar tingkatan dan atau susunan pemerintahan.

Dalam memberikan otonomi untuk pelayanan kebutuhan dasar dan pelayanan pengembangan usaha ekonomi masyarakat ada tiga hal yang perlu pertimbangkan yaitu:

1. Akuntabilitas; bahwa penyerahan urusan tersebut akan menciptakan akuntabilitas Pemerintah Daerah kepada masyarakat. Ini berarti bagaimana mendekatkan pelayanan tersebut kepada masyarakat. Makin dekat unit pemerintahan yang memberikan pelayanan kepada masyarakat akan makin mendukung akuntabilitas.

2. Efisiensi; bahwa penyerahan urusan tersebut akan menciptakan efisiensi, efektifitas dan ekonomis dalam penyelenggaraannya. Ini berkaitan dengan economies of scale (skala ekonomis) dalam pemebrian pelayanan tersebut. Untuk itu harus terdapat kesesuaian antara skala ekonomis dengan catchment area (daerah pelayanan). Persoalannya adalah sejauh mana skala ekonomis tersebut sesuai dengan batas-batas wilayah administrasi Pemerintah Daerah yang sudah ada. Makin luas wilayah pelayanan yang diperlukan untuk mencapai skala ekonomis akan makin tinggi otoritas yang diperlukan. Bandara dan pelabuhan yang menangani antar Propinsi adalah menjadi tanggung jawab nasional.

3. Externalitas; dampak yang ditumbuhkan oleh kegiatan yang memerlukan pelayanan tersebut. Externalitas sangat terkait dengan akuntabilitas. Makin luas externalitas yang ditimbulkan akan makin tinggi otoritas yang diperlukan untuk menangani urusan tersebut. Contoh, sungai atau hutan yang mempunyai externalitas regional seyogyanya menjadi tangung jawab Propinsi untuk mengurusnya.

Konsekwensi dari pendekatan tersebut adalah bahwa untuk pelayanan-pelayanan yang bersifat dasar (basic services) maupun 
pelayanan-pelayanan untuk pengembangan usaha ekonomi masyarakat atas pertimbangan efisiensi, akuntabilitas dan eksternalitas yang bersifat lokal seyogyanya menjadi urusan Kabupaten/Kota, yang bersifat lintas Kabupaten/Kota menjadi urusan propinsi dan yang lintas propinsi menjadi kewenangan pusat.Dalam setiap kebijakan atau keputusan yang diambil pasti ada sisi positif dan sisi negatifnya. Begitu juga dengan penerapan sistem desentralisasi ini, memiliki beberapa kelemahan dan kelebihan.

\section{1) Segi Ekonomi}

Dari segi Ekonomi banyak sekali keuntungan dari penerapan sistem desentalisasi ini dimana pemerintah daerah akan mudah untuk mengelola sumber daya alam yang dimilikinya, dengan demikian, apabila sumber daya alam yang dimiliki telah dikelola secara maksimal maka pendapatan daerah dan pendapatan masyarakat akan meningkat.

\section{2) Segi Sosial Budaya}

Budaya adalah salah satu yang diamanatkan dalam kesatuan kehidupan Republik Indonesia artinya bahwa dengan adanya budaya maka akan memperkuat ikatan sosial budaya pada suatu daerah. Karena dengan diterapkannya sistem desentralisasi ini pemerintah daerah akan dengan mudah untuk mengembangkan kebudayaan yang dimiliki oleh daerah tersebut. Bahkan kebuyaan tersebut dapat dikembangkan dan 
diperkenalkan kepada daerah lain. Yang nantinya merupakan salah satu potensi daerah tersebut.

\section{3) Segi Keamanan dan Politik}

Didalam segi keamanan politik, dengan adanya sistem desentralisasi merupakan suatu upaya untuk mempertahankan kesatuan negara Indonesia, karena dengan diterapkannya kebijakan ini akan bisa meredam daerah-daerah yang ingin memisahkan diri dari NKRI. Tetapi juga disatu sisi otonomi daerah berpotensi menyulut konflik antar daerah.

\section{4) Segi Pelayanan Pemerintah}

Dalam UU Nomor 32 Tahun 2004 tentang Pemerintahan Daerah huruf " $M$ " bahwa pelayanan merupakan kunci utama dalam konteks otonomi daerah, harus mengedepankan pelayanan prima pada masyarakat yang dilakukan secara transparan dan akuntable. Dalam Undang-undang Nomor 14 Tahun 2008 tentang imformasi publik, bahwa masyarakat wajib mengetahui mekanisme pelayanan yang diberikan pemerintah tentunya harus secara transparan.

Regulasi yang baru ini memberikan kewenangan yang luas kepada daerah otonom yang meliputi seluruh bidang pemerintahan kecuali politik luar negeri, hankam, peradilan, moneter dan fiskal, agama, serta beberapa kewenangan bidang lain. Disamping memperoleh kewenangan politik yang luas, daerah juga memperoleh peluang partisipasi politik yang tinggi. Hal ini dapat dilihat dari kesempatan untuk memilih Kepala Daerah secara langsung, juga pembentukan Badan Perwakilan Desa 
sebagai perkembangan baru bagi kehidupan demokrasi ditingkat desa. Secara lebih detail, UU Nomor 22 Tahun 1999 yang kemudian dilanjutkan dengan UU Nomor 32 Tahun 2004 dengan beberapa revisi, telah melakukan perubahan signifikan dibandingkan dengan sistem yang digunakan di masa Orde Baru.

Pertama, semangat otonomi daerah yang lebih besar ini dimulai dengan perubahan simbolisasi pada nama daerah otonom. Istilah tingkatan daerah otonom (Dati I dan Dati II) dihapuskan, dan diganti dengan istilah yang lebih netral, yaitu Propinsi, Kabupaten dan Kota. Hal ini didasari semangat untuk menghindari citra bahwa tingkatan lebih tinggi (Dati I) secara hierarkhis lebih berkuasa daripada tingkatan lebih rendah (Dati II). Padahal dua-duanya merupakan badan hukum yang terpisah dan sejajar yang mempunyai kewenangan berbeda.

Kedua, UU Nomor 22 Tahun 1999 memperpendek jangkauan asas dekonsentrasi yang dibatasi hanya sampai pemerintahan Propinsi. Pemerintahan Kabupaten dan Kota telah terbebas dari intervensi pusat yang sangat kuat melalui perangkapan jabatan kepala daerah otonom (local self-government) dan kepala wilayah administratif (field administration). Bupati dan Walikota adalah Kepada Daerah otonom saja. Sementara itu jabatan kepala wilayah pada kabupaten dan kota (dulu kotamadya) sudah tidak dikenal lagi.

Ketiga, Bupati dan Walikota dipilih secara mandiri di daerah tanpa melibatkan pemerintah Propinsi maupun pemerintah Pusat. Dalam UU Nomor 22 Tahun 1999, Kepala Daerah dipilih oleh DPRD. Oleh karena itu, Bupati/Walikota harus bertanggung jawab kepada dan bisa 
diberhentikan oleh DPRD sebelum masa jabatannya usai. Sementara itu, pemerintah pusat (Presiden) hanya diberi kekuasaan untuk 'memberhentikan sementara' seorang Bupati/Walikota jika dianggap membahayakan integrasi nasional. Pada Tahun 2004, diperkenalkanlah Pilkada Langsung di mana Kepala Daerah dipilih secara langsung oleh rakyat dari para pasangan calon yang diajukan oleh partai politik. Perubahan ke arah pendalaman demokrasi ini terus berkembang. UU Nomor 32 Tahun 2004 ini kemudian direvisi di Tahun 2008 dengan memberikan kesempatan kepada calon perseorangan untuk berkompetisi dalam Pilkada Langsung.

Keempat, UU Nomor 22 Tahun 1999 yang kemudian dilanjutkan oleh UU Nomor 32 Tahun 2004 menghapuskan posisi wilayah administratif (field administration) pada level Daerah Kabupaten dan Daerah Kota. Integrated Prefectoral System yang sentralistis yang digunakan UU Nomor 5 Tahun 1974 diubah menjadi Functional System, dan bukan sekedar Unintegrated Prefectoral System yang dikenal pada UU Nomor 1 Tahun 1957.

Kelima, UU tersebut menempatkan pemerintahan kecamatan dan kelurahan sebagai perangkat Daerah otonom, yaitu Daerah Kabupaten dan Daerah Kota. Dengan kata lain, pemerintahan kecamatan menempati posisi sebagai kepanjangan tangan pemerintahan daerah otonom (desentralisasi), dan bukan sebagai aparat dekonsentrasi.

Keenam, UU ini memberikan kewenangan yang lebih luas kepada daerah otonom yang meliputi seluruh bidang pemerintahan kecuali 
politik luar negeri, hankam, peradilan, moneter dan fiskal, agama, serta 'kewenangan bidang lain'. Hanya saja, definisi 'kewenangan bidang lain' ini ternyata masih sangat luas, sebab mencakup perencanaan dan pengendalian pembangunan nasional secara makro, dana perimbangan keuangan, sistem administrasi negara dan lembaga perekonomian negara, pembinaan dan pemberdayaan SDM, pendaya gunaan SDA serta teknologi tinggi strategis, koservasi dan standarisasi nasional.

Sementara itu, keuangan daerah juga mengalami beberapa perubahan. Sejak UU Nomor 25 Tahun 1999 yang di ganti dengan UU Nomor 33 Tahun 2004, secara makro sumber-sumber keuangan daerah diperbesar, sejalan dengan dikembangkannya prinsip perimbangan. Berdasarkan pada PP Nomor 78 Tahun 2007 sebagai pengganti dari PP Nomor 129 Tahun 2000 tentang Tata cara penghapusan, pembentukan dan penggabungan daerah, akan tetapi di Wilayah III Cirebon meliputi Daerah kab/kota Cirebon, kabupaten majalengka, kabupaten Indramayu, Kabupaten kuningan, sebagian masyarakat mengupayakan terjadinya pemekaran untuk menjadi daerah Propinsi Cirebon karena telah memenuhi syarat minimal 5 (lima) daerah Kabupaten/Kota. ${ }^{3}$

Berdasarkan cluster estimasi pemekaran daerah Kabupaten/Kota di daerah Propinsi jawa barat Tahun 2010-2025 akan bertambah 4 (empat) daerah Kabupaten/Kota hasil pemekaran (DOB), yang awalnya ada 26 daerah kab/kota, hingga Tahun 2025 akan bertambah menjadi 30 daerah otonomi baru (DOB) hasil pemekaran.

3 Kementrian Dalam Negeri RI, Desain Besar Penataan Daerah di Indonesia Tahun 2010-2025, Estimasi Jumlah Maksimal Propinsi dan Daerah Kab/Kota, hlm 55. 
Namun Untuk pemekaran Propinsi di Wilayah Jawa hingga Tahun 2025, menurut Desain besar (Grand desain ) penataan daerah di Indonesia tertutup, tidak ada pemekaran daerah Propinsi, termasuk untuk Propinsi Cirebon yang telah di usulkan ke Mentri Dalam Negeri (Mendagri) dan DPR RI. ${ }^{4}$

Atas pertimbangan tersebut gambaran tentang dampak dari pelaksanaan otonomi daerah dalam tulisan ini diletakkan dalam wajah ganda. Menghindari ataupun meminimalisasi dampak negatif pada dasarnya adalah mengelola proses kebijakan pelaksanaan otonomi daerah dan proses pasca pelaksanaan otonomi daerah.

\section{1) Dampak Sosio Kultural}

Pelaksanaan otonomi daerah membawa implikasi positif dalam bentuk pengakuan sosial, politik dan kultural masyarakat daerah. Melalui kebijakan otonomi daerah entitas masyarakat yang mempunyai sejarah kohesivitas dan kebesaran yang panjang, memperoleh pengakuan sebagai daerah otonom baru. Pengakuan ini pada gilirannya memberikan kontribusi positif terhadap kepuasan masyarakat, sehingga meningkatkan dukungan daerah terhadap pemerintah nasional.

Namun demikian, kebijakan otonomi daerah juga bisa memicu konflik yang pada gilirannya juga menimbulkan masalah horisontal dan vertikal dalam masyarakat. Sengketa antara pemerintah daerah induk dengan pemerintah daerah pemekaran dalam hal pengalihan

4 Pratikno, Hubungan Pusat dan Daerah: Gelombang Ketiga, Jurnal Ilmu-Ilmu Sosial UNISIA No. 39/XXII/III/1999. 
aset dan batas wilayah, seringkali berimplikasi pada ketegangan antar kubu masyarakat dan antara masyarakat dengan pemerintah daerah.

\section{2) Dampak Pada Pelayanan Publik}

Kebijakan otonomi daerah mampu memperpendek jarak geografis antara pemukiman penduduk dengan sentra pelayanan, juga mempersempit rentang kendali antara pemerintah daerah dengan unit pemerintahan di bawahnya. Disamping itu, pelaksanaan otonomi daerah juga memungkinkan untuk menghadirkan jenis-jenis pelayanan baru, seperti pelayanan listrik, telepon, serta fasilitas urban lainnya, terutama di wilayah ibukota daerah otonom.

Tetapi, pelaksanaan otonomi daerah juga menimbulkan implikasi negatif bagi pelayanan publik, terutama pada skala nasional, terkait dengan alokasi anggaran untuk pelayanan publik yang berkurang. Hal ini disebabkan adanya kebutuhan belanja aparat dan infrastruktur pemerintahan lainnya yang bertambah dalam jumlah yang signifikan sejalan dengan pembentukan DPRD dan birokrasi di daerah hasil otonom.

\section{3) Dampak Bagi Pembangunan Ekonomi}

Pasca terbentuknya daerah otonom baru, terdapat peluang yang besar bagi akselerasi pembangunan ekonomi di wilayah yang baru. Bukan hanya infrastruktur pemerintahan yang terbangun, tetapi juga infrastruktur fisik dan infrastruktur kebijakan pembangunan ekonomi yang dikeluarkan oleh pemerintah daerah otonom baru. Semua infrastruktur ini membuka peluang yang lebih 
besar bagi wilayah hasil otonom untuk mengakselerasi pembangunan ekonomi.

\section{4) Dampak Bagi Pertahanan, Keamanan dan Integrasi Nasional}

Pembentukan daerah otonom baru, bagi beberapa masyarakat pedalaman dan masyarakat di Wilayah perbatasan merupakan isu politik nasional yang penting. Bagi masyarakat tersebut, bisa jadi mereka tidak pernah melihat dan merasakan kehadiran 'Indonesia', baik dalam bentuk simbol pemerintahan, politisi, birokrasi dan bahkan kantor pemerintah. Pemekaran daerah otonom, oleh karenanya, bisa memperbaiki kenangan politik nasional di daerah melalui peningkatan dukungan terhadap pemerintah nasional dan menghadirkan pemerintah pada level yang lebih bawah.

Identifikasi dampak pelaksanaan otonomi daerah tersebut membawa kita pada kesimpulan bahwa banyak dampak negatif yang perlu diminimalisasi. Esensi kebijakan yang ada perlu dilakukan adalah merasionalisasi proses kebijakan UU tentang otonomi daerah, baik proses pengusulan kemandirian yang dilakukan oleh daerah Kabupaten/Kota, maupun proses penetapan daerah otonom yang dilakukan ditingkat pusat. Dalam uraian berikut ini kita akan memahami proses dalam dua tingkatan tersebut yang akan membawa kita pada usulan rasionalisasi proses kebijakan otonom demi optimalisasi kepentingan publik. 


\section{E. Penutup \\ a. Kesimpulan}

Pelaksanaan otonomi daerah Kabupaten/Kota di Wilayah III Cirebon menunjukan telah tercapainya tingkat keberhasilan dengan baik sesuai yang diamanatkan dalam Pasal 18 UUD 1945 amandemen ke II jo Undang-undang Nomor 32 Tahun 2004 tentang Pemerintahan Daerah. Tingkat keberhasilan tersebut untuk mempercepat terwujudnya kesejahtraan masyarakat melalui peningkatan pelayanan dasar yaitu penyelenggaraan pendidikan dasar, pelayanan kesehatan, pemenuhan kebutuhan hidup minimal (daya beli masyarakat), prasarana lingkungan dasar, pemberdayaan serta peran masyarakat sebagai wujud keberhasilan tersebut dapat dilihat dari aspek peningkatan PADS dan APBD serta peningkatan IPM.Pelaksanaan otonomi daerah kabupaten/kota di Wilayah III Cirebon belum sepenuhnya menjiwai (mewujudkan) pemahaman dalam penyelenggaraan pemerintahan daerah menurut Undang-undang Nomor 32 Tahun 2004 sebagai implementasi terhadap Pasal 18 ayat (5) UUD 1945 Amandemen ke-II, karena pelaksanaan otonomi daerah yang dititik beratkan pada daerah kabupaten/kota untuk menjalankan otonomi yang seluas-luasnya tersebut belum terlihat adanya kemandirian.

\section{b. Saran}

Dengan adanya pelaksanaan otonomi daerah yang di tegaskan dalam pasal 18 UUD 1945 amandemen ke II akan memperkokoh terhadap keutuhan NKRI. Karena pelaksanaan otonomi daerah yang seluas-luasnya ditekankan pada daerah kabupaten/kota. 


\section{DAFTAR PUSTAKA}

\section{A. BUKU:}

A.Gafar Syaukani,dan R.Rasyid, 2004, Otonomi Daerah dalam Negara Kesatuan,Yogyakarta, Pustaka Pelajar.

A. Hamid Attamimi, 1990, Peraturan Keputusan Presiden Republik Indonesia dalam Penyelenggaraan Pemerintahan Negara, Jakarta, Disertasi Fakultas Pascasarjana Universitas Indonesia,.

Agus Dwiyanto, 2001, Reformasi Birokrasi Publik di Indonesia, Yogyakarta, Pusat Studi Kependudukan dan Kebijakan (PSKK) UGM.

Agus Salim Andi Gadjong, 2007, Pemerintahan Daerah Kajian Politik Dan Hukum,Bogor, Ghalia Indonesia.

Ahmad Yani, 2002, Hubungan Keuangan antara Pemerintah Pusat dan Daerah, Jakarta, Raja Grafindo Persada.

Alien, H.JB,1982, Enhancing Decentralisation for Developemnt, The Hague:IULA.Bina Aksara.

Amrah Muslimin, 1986, Aspek-aspek Hukum Otonomi Daerah, Alumni Bandung Tahun.

1960, Ikhtisar Perkembangan Otonomi Daerah 1903-1958, Jakarta, Penerbit Djambatan.

"Pemerintahan Daerah Menurut Perundang-undangan yang Terakhir-1957",Jakarta, Budhi Dharma.

Andrian Sutedi, 2009, Implikai Hukum atau Sumber Pembiayaan Daerah dalam Kerangka Otonomi Daerah, Jakarta, Sinar Grafika.

Anhar Gonggong (ed), 2005, Pasang Surut Otonomi Daerah-Sketsa Perjalanan 100 Tahun, Jakarta, Institute for Local Development.

APAKSI,2001, Himpunan Peraturan Pelaksanaan Undang-undang No.22 Tahun 1999 dan Undang-undang No.25 Tahun 1999",Jakarta, APKSI.

Ateng Syafruddin, 1991, Titik Berat Otonomi Daerah Pada Daerah Tingkat II dan Perkembangannya, Bandung: Mandar Maju. 
Ateng Syafrudin,1982, Hubungan Kepala Daerah dengan DPRD, Bandung: Tarsito.

Ateng Syafrudin,1993, Pengaturan Koordinasi Pemerintahan di Daerah,Bandung, PT. Citra Aditya Bhakti.

Ateng Syafrudin, 1985, Pasang Surut Otonomi Daerah, Bandung: Binacipta.

Azhari,1995, Negara Hukum Indonesia, Analisis Yuridis Normatif tentang Unsur-Unsurnya, Jakarta, UI-Press.

B.Arief Sidharta dkk.(eds.), 1996, Butir-butir Gagasan tentang Penyelenggaraan Hukum dan Pemerintahan yang Layak (Sebuah Tanda Mata bagi 70 Tahun Prof.Dr.Ateng Syafrudin,S.H.),Bandung, PT.Citra Aditya Bakti.

Bagir Manan,1993, Perjalanan Historis Pasal 18 UUD 1945, Jakarta, UNSIKA.

Bagir Manan, 1994, Hubungan antara Pemerintah Pusat dan Daerah menurut UUD 1945, Jakarta, Pustaka Sinar Harapan.

Bagir Manan, Menyongsong Fajar Otonomi Daerah, Yogyakarta: PSH FHUII.

Bagir Manan, 1990, Hubungan Antara Pusat Dan Daerah Berdasrakan Asas Desentralisasi Menurut UUD 1945,Bandung, UNPAD.

Bambang Yudoyono, 2001, Otonomi Daerah Desentralisasi dan Pengembangan SDM Aparatur Pemerintah Daerah dan Anggota DPRD, Pustaka Harapan.

Bambang Yudoyono, 2001, Otonomi Daerah, Desentralisasi dan Pengembangan SDM Aparatur Pemda dan Anggota DPRD. Jakarta: Pustaka Sinar Harapan. 